\title{
Superoxide dismutase and lipid hydroperoxides in blood and endometrial tissue of patients with benign, hyperplastic and malignant endometrium
}

\author{
SNEŽANA PEJIĆ ${ }^{1}$, ANA TODOROVIĆ ${ }^{1}$, VESNA STOJILJKOVIĆ ${ }^{1}$, DRAGANA CVETKOVIĆ ${ }^{3}$, \\ NENAD LUČIĆ ${ }^{2}$, RATKO M. RADOJIČIĆ ${ }^{4}$, ZORICA S. SAIČIĆ ${ }^{5}$ and SNEŽANA B. PAJOVIĆ ${ }^{1}$ \\ ${ }^{1}$ Laboratory of Molecular Biology and Endocrinology, Vinča Institute of Nuclear Sciences \\ P.O. Box 522, 11001 Belgrade, Serbia \\ ${ }^{2}$ Clinic for Gynecology and Maternity, Clinical Centre, Ulica 12 beba bb, 51000 Banja Luka, Bosnia and Herzegovina \\ ${ }^{3}$ Institute of Zoology, Faculty of Biology, University of Belgrade, Studentski trg 3, 11060 Belgrade, Serbia \\ ${ }^{4}$ Institute for Biochemistry and Physiology, Faculty of Biology, University of Belgrade \\ Studentski trg 3, 11060 Belgrade, Serbia \\ ${ }^{5}$ Institute for Biological Research, Siniša Stanković, Department of Physiology, Bulevar despota Stefana 142 \\ 11060 Belgrade, Serbia
}

Manuscript received on August 10, 2007; accepted for publication on April 14, 2008; presented by ALEXANDER W.A. KELLNER

\begin{abstract}
Epidemiological and experimental data point to involvement of oxygen derived radicals in the pathogenesis of gynecological disorders, as well as in cancer development. The objective of the present study was to examine changes in activities and levels of copper/zinc superoxide dismutase (CuZnSOD) and lipid hydroperoxides (LOOH) in blood and endometrial tissue of patients diagnosed with uterine myoma, endometrial polypus, hyperplasia simplex, hyperplasia complex and adenocarcinoma endometrii. The results of our study have shown decreased SOD activities and unchanged SOD protein level in blood of all examined patients in comparison to healthy subjects. Decrease of both SOD activity and level was found in endometrium of patients with hyperplasia simplex, hyperplasia complex and adenocarcinoma in comparison to women with polypus or myoma. $\mathrm{LOOH}$ level was elevated in both tissues of patients with hyperplasia or adenocarcinoma in comparison to healthy subjects or patients with benign diagnosis. Our findings suggest that the decrease in SOD activity and level, as well as the increase in LOOH level, in patients with gynecological disorders, render these patients more susceptible to oxidative damage caused by reactive oxygen species (ROS). An imbalance in ROS formation and SOD level may be important in the pathogenesis and/or perpetuation of tissue damage in gynecological patients. Since evidence suggests that SOD may be a therapy target for cancer treatment, our findings provide a basis for further research and options for clinical applications.
\end{abstract}

Key words: copper/zinc superoxide dismutase, lipid hydroperoxides, uterine myoma, endometrial polypus, endometrial hyperplasia, endometrial adenocarcinoma.

\section{INTRODUCTION}

Reactive oxygen species (ROS), such as superoxide $\left(\mathrm{O}_{2}^{-}\right)$and hydrogen peroxide $\left(\mathrm{H}_{2} \mathrm{O}_{2}\right)$, are produced in metabolic processes. A balance between $\mathrm{O}_{2}^{--}$production and elimination is important for maintenance of a proper

Correspondence to: Dr. Snežana Pejić

E-mail: snezana@vin.bg.ac.yu redox state in the cell (Dröge 2002). Under physiological conditions, ROS generation, including lipid peroxidation (LPO), is counterbalanced by the action of antioxidant enzymes (AOE) such as superoxide dismutases (SODs), cytosolic copper/zinc SOD (CuZnSOD) and mitochondrial manganese SOD (MnSOD), catalase (CAT), and various glutathione peroxidases (GPx) (Zelko et al. 2002, Brigelius-Flohé 2006). It is also well known that 
ROS participate in the pathogenesis of various diseases including carcinogenesis (Valko et al. 2007).

Endometrial carcinoma is the most frequently diagnosed malignancy of the female genital tract. It is often preceded by histopathologic lesions known as endometrial hyperplasia (Mutter 2002), and it is generally considered a precursor of endometrial cancer (Münstedt et al. 2004). According to the current World Health Organization (WHO) nomenclature, endometrial hyperplasia is classified in four categories, simple hyperplasia (SH), complex hyperplasia $(\mathrm{CH})$, simple atypical hyperplasia (SAH) and complex atypical hyperplasia (CAH).

In recent years, there has been a growing interest in the investigation on the role played by ROS and antioxidants in gynecological patients. Chiou and $\mathrm{Hu}$ (1999) reported on the elevated LPO and decreased plasma and erythrocytes SOD activity in both uterine cervicitis and myoma patients, while activities of CAT and GPx were elevated in cervicitis patients and lowered in myoma patients. Similar observations were made on erythrocytes SOD, CAT and GPx activities of cervicitis patients, whereas activities of examined enzymes decreased in cervical cancer patients (Manoharan et al. 2004). LPO was found to be increased in both groups of patients (Manoharan et al. 2004). In endometrial cancer tissue of both Finnish and Japanese women, the activity of SOD was found to be significantly lower than in normal endometrium (Punnonen et al. 1993). Our recent results showed that SOD activity was lower in the blood of patients with uterine polypus or myoma, hyperplasia endometrii and adenocarcinoma endometrii than in that of healthy subjects (Pejić et al. 2006). There is a limited amount of information regarding the relative levels of SOD expression in gynecological patients. It was shown that levels of both CuZnSOD and MnSOD in endometriosis and adenomyosis were persistently higher than their respective levels throughout the menstrual cycle in fertile controls (Ota et al. 1999). Increase in SOD level has also been observed in ovarian cancer patients $(\mathrm{Hu}$ et al. 2005). Other studies showed that SOD levels in various cancer tissues were unchanged or lower than in normal tissue (Bostwick et al. 2000, Monari et al. 2006).

The aim of this study was to investigate changes in CuZnSOD activities and protein levels, as well as LPO level in blood and endometrial tissue of patients diagnosed with uterine myoma, endometrial polypus, hyperplasia simplex, hyperplasia complex and adenocarcinoma endometrii.

\section{MATERIALS AND METHODS}

\section{SUBJECTS}

The material used in this study comprised 103 blood samples and 88 tissue specimens of women admitted to the Department of Gynecology and Obstetrics for gynecological evaluation within routine checkups or for abnormal uterine bleeding. The specimens were taken after obtaining informed consent and the study was conducted prospectively. The protocol followed is consistent with the World Medical Association Declaration of Helsinki (Ethical Principles for Medical Research Involving Human Subjects).

On the basis of diagnosis and histological examination, subjects were divided into the following groups: healthy control patients $(\mathrm{C}, \mathrm{n}=15$, mean \pm SEM: $49 \pm$ $3 \mathrm{yr}$ ); patients with benign uterine changes: polypus endometrii (PE, $\mathrm{n}=18,45 \pm 3 \mathrm{yr}$ ) or uterus myomatosus (UM, $\mathrm{n}=12,47 \pm 2 \mathrm{yr})$; patients with abnormal bleeding: hyperplasia simplex endometrii $(\mathrm{SH}, \mathrm{n}=31$, $48 \pm 1 \mathrm{yr})$, hyperplasia complex endometrii $(\mathrm{CH}, \mathrm{n}=22$, $48 \pm 2 \mathrm{yr}$ ) or adenocarcinoma endometrii, stage I (ACE, $\mathrm{n}=5,59 \pm 3 \mathrm{yr})$.

\section{SAMPLES}

Venous blood samples were collected into heparinized tubes on the same day of endometrial biopsy and aliquoted immediately. For SOD assay (OxisResearch ${ }^{\mathrm{TM}}$ ), blood was centrifuged at $2500 \mathrm{~g}$ for $5 \mathrm{~min}$. Plasma was discarded and the pellet resuspended in 4 packed-cell volume of ice-cold demineralized ultrapure water (MilliQ reagent grade water system, Millipore Corp., Bedford, MA, USA). After the addition of ethanol/chloroform extraction reagent $(62.5 / 37.5 \mathrm{vol} / \mathrm{vol})$ to remove hemoglobin, samples were centrifuged at $3000 \mathrm{~g}$ for $10 \mathrm{~min}$ (Eppendorf centrifuge 5417, Eppendorf AG, Hamburg, Germany). The upper aqueous layer was collected and stored at $-70^{\circ} \mathrm{C}$ until assay.

Endometrial tissue samples were washed in saline solution and homogenized in phosphate buffer containing $0.05 \mathrm{M} \mathrm{KH}_{2} \mathrm{PO}_{4}$ and $1 \mathrm{mM}$ EDTA, $\mathrm{pH} 7.8$ ( $1 \mathrm{~g}$ tissue per $2 \mathrm{ml}$ buffer) in a Teflon/glass homogenizer (Spindler 
\& Hoyer, Göttingen, Germany) and frozen at $-70^{\circ} \mathrm{C}$ for $20 \mathrm{~h}$ to disrupt cell membranes. For SOD assay $\left(\right.$ OxisResearch ${ }^{\mathrm{TM}}$ ), thawed homogenates were vortexed for $1 \mathrm{~min}$ and centrifuged at $8600 \mathrm{~g}$, for $20 \mathrm{~min}$ at $4^{\circ} \mathrm{C}$ (Eppendorf centrifuge 5417, Eppendorf AG, Hamburg, Germany). According to the manufacturer's recommendation, after addition of ethanol/chloroform extraction reagent $(62.5 / 37.5 \mathrm{vol} / \mathrm{vol})$ to completely remove hemoglobin, samples were centrifuged at $6000 \mathrm{~g}$ for $20 \mathrm{~min}$ (Beckman centrifuge J2-21, Beckman Instruments Inc., Palo Alto, CA, USA). The upper aqueous layer was collected and stored at $-70^{\circ} \mathrm{C}$ until assay. SOD assay was performed spectrophotometrically (Perkin Elmer Spectrophotometer, Lambda 25, Perkin Elmer Instruments, Norwalk, CT, USA). The specific enzyme activity was expressed as Units (U) per milligram of total protein (U/mg protein). Determination of protein concentration was performed in crude hemolysates using the method of Lowry et al. (1951) and expressed as $\mathrm{mg} / \mathrm{ml}$.

\section{SOD ACTIVITY ASSAY}

Determination of SOD activity was performed using Oxis Bioxytech ${ }^{\circledR}$ SOD-525 $5^{\mathrm{TM}}$ Assay (Oxis International, Inc., Portland, OR, USA). The method is based on SOD-mediated increase of autoxidation of 5,6,6a11btetrahydro-3,9,10-tryhydroxybenzo[c]fluorene in aqueous alkaline solution to yield a chromophore with maximum absorbance at $525 \mathrm{~nm}$. The SOD activity is determined from the ratio of the autoxidation rates in the presence $(\mathrm{Vs})$ and absence $(\mathrm{Vc})$ of SOD. One SOD-525 activity unit is defined as the activity that doubles the autoxidation rate of the blank control.

\section{LIPID HYDROPEROXIDES}

LOOH was measured by Oxis Bioxytech ${ }^{\circledR}$ LPO- $560^{\mathrm{TM}}$ Assay (Oxis International, Inc., Portland, OR, USA), which is based on the oxidation of ferrous $\left(\mathrm{Fe}_{2+}\right)$ ions to ferric $\left(\mathrm{Fe}_{3+}\right)$ ions by hydroperoxides, in acidic conditions. Ferric ions then bind to the indicator dye, xylenol orange, yielding a colored complex. The absorbance of the complex was measured at $560 \mathrm{~nm}$. Since hydrogen peroxide content in many biological samples is much higher than that of other hydroperoxides, samples were pretreated with catalase to decompose the existing $\mathrm{H}_{2} \mathrm{O}_{2}$ and eliminate the interference. $\mathrm{LOOH}$ concentration was expressed as $\mathrm{nmol} / \mathrm{mg}$ protein.

\section{WESTERN BLOTTING}

Equal amounts of protein were dissolved in SDS-PAGE sample loading buffer and electrophoresed in polyacrylamide gel (10\%), according to Laemmli (1970). For Western blotting, the proteins were transferred to nitrocellulose membranes. Non-specific binding sites on membranes were blocked with TBST (10 mM Tris, $150 \mathrm{mM} \mathrm{NaCl}, 0.1 \%$ Tween 20) containing $1 \%$ BSA and then probed with rabbit anti-CuZnSOD polyclonal antibody (SOD-100, Stressgen Biotechnologies; 1:7500). After the blots were washed, alkaline phosphatase-conjugated goat anti-rabbit IgG (SAB-301, Stressgen Biotechnologies; 1:7500) was added. Each blot was triplicated and scanned. The density of bands was determined by ImageJ processing software and normalized to the loading control.

\section{Statistical Analysis}

Statistical analysis was carried out using the KruskalWallis method, whereas significances were evaluated by Mann-Whitney test (values marked with asterisk(s) are significantly different from control: ${ }^{*} \mathrm{p}<0.05,{ }^{* *} \mathrm{p}<$ $0.01,{ }^{* * *} \mathrm{p}<0.001$ ) and Dunn's test (values with different letter designations are significantly different, $\mathrm{p}<0.05$ ). Spearman's rank correlation coefficient was used to investigate associations between lipid peroxidation and SOD activities. Two-tailed $p$ values are given throughout. All data were analyzed using GraphPad Prism 4 software.

\section{RESULTS}

Superoxide dismutase activity in blood is shown in Figure 1 . The obtained values showed significant variation among the examined groups $(\mathrm{H}=46.83, \mathrm{df}=5$, $\mathrm{p}<0.001)$. The activity was $26 \%(\mathrm{p}<0.05)$ and $20 \%$ $(\mathrm{p}>0.05)$ lower in polypus and myoma patients, respectively, than in controls. It was also significantly decreased in patients suffering from hyperplasia simplex $(42 \%, \mathrm{p}<0.001)$, hyperplasia complex $(45 \%, \mathrm{p}<$ $0.001)$ and adenocarcinoma $(53 \%, \mathrm{p}<0.01)$. A significant difference between hyperplasia or adenocarcinoma patients and those suffering from myoma was also observed $(\mathrm{p}<0.05)$.

Compared to control group values, protein levels of SOD in blood (Fig. 2) were not significantly changed 


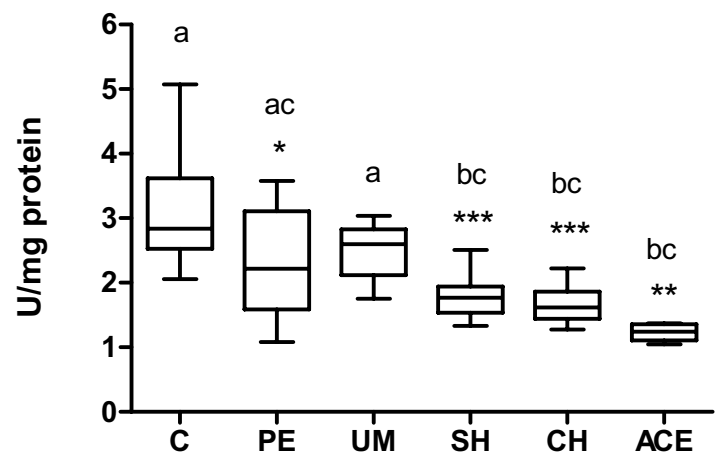

Fig. $1-$ CuZnSOD activity in the blood of control patients (C) and patients diagnosed with: polypus endometrii (PE), uterus myomatosus (UM), simple hyperplasia ( $\mathrm{SH})$, complex hyperplasia $(\mathrm{CH})$ and adenocarcinoma endometrii (ACE). Mean SOD activities $( \pm \mathrm{SD})$ are represented by the box; medians are plotted inside the box; the whiskers extend to the $5^{\text {th }}$ and $95^{\text {th }}$ percentiles. Values which are not designated by the same letter $(a, b, c)$ are significantly different $(\mathrm{p}<0.05)$. Values marked with asterisk(s) are significantly different $(* \mathrm{p}<0.05$, ${ }^{* *} \mathrm{p}<0.01,{ }^{* * *} \mathrm{p}<0.001$ ) than the control (Pejić et al. 2006).

in all examined patients $(\mathrm{p}>0.05)$. Also, there were no significant differences of SOD protein levels among the patient groups ( $\mathrm{p}>0.05)$.

In endometrium of the same patients (Fig. 3), SOD activity was similar in polypus and myoma patients. However, compared to subjects with benign endometrial changes (polypus and myoma), SOD activity was significantly lower in patients suffering from hyperplasia simplex $(\sim 41 \%)$, hyperplasia complex $(\sim 53 \%)$ and adenocarcinoma $(\sim 72 \%)(\mathrm{p}<0.05)$.

Similarly, SOD protein levels were found to be significantly decreased $(\mathrm{p}<0.05)$ in the endometrium of patients diagnosed with hyperplasia simplex $(\sim 30 \%)$, hyperplasia complex ( 44\%) and adenocarcinoma $(\sim 54 \%)$, compared to polypus or myoma subjects (Fig. 4).

LOOH level (Table I) showed significant variation among the examined groups in blood plasma $(\mathrm{H}=23.38$, $\mathrm{df}=5, \mathrm{p}<0.001)$ and endometrial tissue $(\mathrm{H}=37.11 \mathrm{df}$ $=4, \mathrm{p}<0.001)$. Compared to controls, moderate elevation of lipid hydroperoxides in plasma was observed in patients diagnosed with polypus endometrii or uterine myoma ( $4 \%$ and $27 \%$, respectively, $\mathrm{p}>0.05$ ) whereas it was significantly higher in both types of hyperplasia (SH: 41\%, CH: 52\%, p < 0.001) and adenocarcinoma $(57 \%, \mathrm{p}<0.01)$. Also, in patients with simple hyperpla-
A

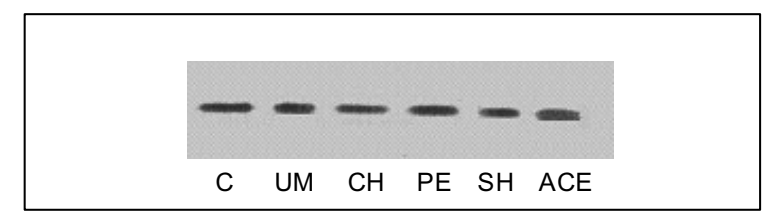

B

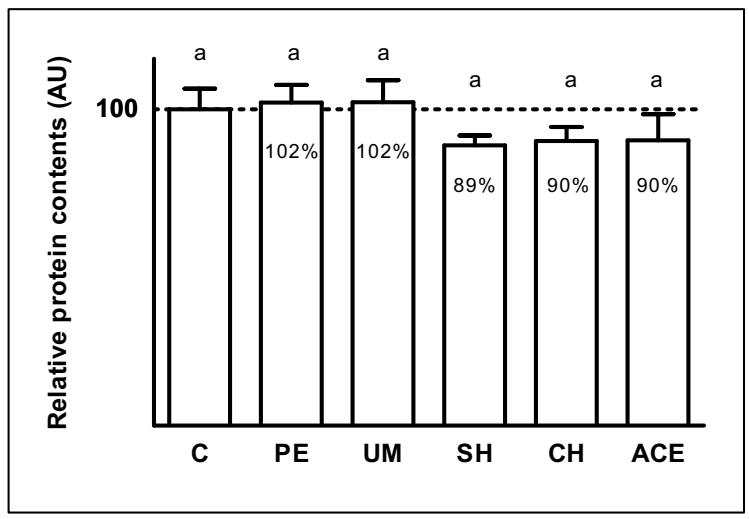

Fig. 2 - A. Relative protein contents. Example of Western blot immunoassay for CuZnSOD in blood of control patients $(\mathrm{C})$ and patients diagnosed with polypus endometrii (PE), uterus myomatosus (UM), simple hyperplasia $(\mathrm{SH})$, complex hyperplasia $(\mathrm{CH})$ and adenocarcinoma endometrii (ACE). B. Comparison of relative SOD protein contents in the blood of control patients $(\mathrm{C})$ and patients diagnosed with polypus endometrii (PE), uterus myomatosus (UM), simple hyperplasia $(\mathrm{SH})$, complex hyperplasia $(\mathrm{CH})$ and adenocarcinoma endometrii (ACE). Values are expressed in arbitrary units (AU), as a percent of the protein content in controls which is considered as $100 \%$ (mean $\pm \mathrm{SEM}$ ).

sia, levels of $\mathrm{LOOH}$ were higher than in patients with polypus $(\mathrm{p}<0.05)$.

LOOH level in endometrial tissue was significantly increased in patients with simple or complex hyperplasia $(\sim 50 \%)$ and adenocarcinoma $(\sim 100 \%)$, compared to polypus or myoma subjects.

We found a negative correlation between the level of lipid hydroperoxides and SOD activity in blood $(\mathrm{r}=$ $-0.33, \mathrm{p}<0.001)$ and endometrial tissue $(\mathrm{r}=-0.21$, $\mathrm{p}<0.05$ ) of the examined patients.

\section{DISCUSSION}

The role of reactive oxygen species in the transformation of a normal cell into a malignant one has been a major focus of recent research. Free radicals have been implicated in many disease processes including cancer, while 
TABLE I

LOOH concentration in plasma and endometrial tissue of control patients $(C)$ and patients diagnosed with: polypus endometrii (PE), uterus myomatosus (UM), simple hyperplasia (SH), complex hyperplasia $(\mathrm{CH})$ and adenocarcinoma endometrii (ACE), (mean $\pm \mathrm{SD})$.

\begin{tabular}{c|c|c|c|c|c|c}
\hline Parameters/Patients & C & PE & UM & SH & CH & ACE \\
\hline $\begin{array}{c}\text { Plasma LOOH } \\
\text { (nmol/mg protein) }\end{array}$ & $0.19 \pm 0.02^{\mathrm{a}}$ & $0.20 \pm 0.09^{\mathrm{ac}}$ & $0.24 \pm 0.04^{\mathrm{ad} \mathrm{d}^{*}}$ & $0.27 \pm 0.07^{\mathrm{bd}^{* * *}}$ & $0.27 \pm 0.07^{\mathrm{bcd} \mathrm{d}^{* * *}}$ & $0.29 \pm 0.04^{\mathrm{bcd} \mathrm{d}^{* *}}$ \\
\hline $\begin{array}{c}\text { Endometrial } \\
\text { tissue LOOH } \\
\text { (nmol/mg protein) }\end{array}$ & & $0.22 \pm 0.06^{\mathrm{a}}$ & $0.24 \pm 0.09^{\mathrm{a}}$ & $0.33 \pm 0.09^{\mathrm{b}}$ & $0.34 \pm 0.07^{\mathrm{b}}$ & $0.47 \pm 0.08^{\mathrm{b}}$ \\
\hline
\end{tabular}

Values with different letter designations are significantly different $(\mathrm{p}<0.05)$. Values marked with asterisks are significantly different $\left({ }^{*} \mathrm{p}<0.05\right.$, $\left.* * \mathrm{p}<0.01,{ }^{* * *} \mathrm{p}<0.001\right)$ from the control.

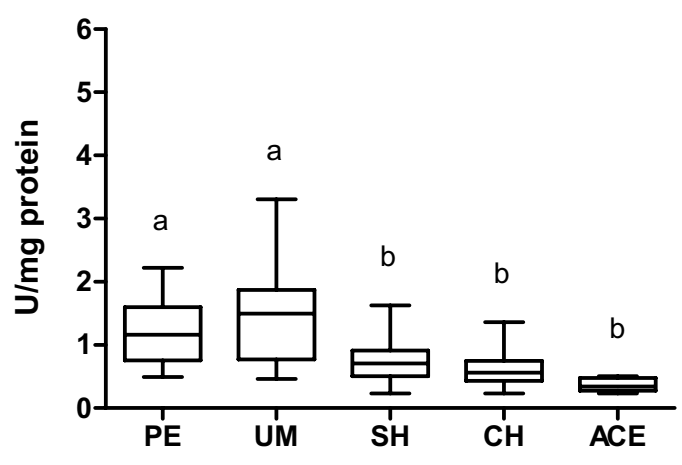

Fig. 3 - CuZnSOD activity in the endometrium of patients diagnosed with: polypus endometrii (PE), uterus myomatosus (UM), simple hyperplasia $(\mathrm{SH})$, complex hyperplasia $(\mathrm{CH})$ and adenocarcinoma endometrii (ACE). Mean SOD activities $( \pm \mathrm{SD})$ are represented by the box; medians are plotted inside the box; the whiskers extend to the $5^{\text {th }}$ and $95^{\text {th }}$ percentiles. Values not designated by the same letter $(\mathrm{a}, \mathrm{b})$ are significantly different $(\mathrm{p}<0.05)$.

superoxide dismutases are the main enzymes responsible for the elimination of superoxide radicals and are considered to be key antioxidants in aerobic cells (Hileman et al. 2001).

In the blood of the examined patients, SOD activities were decreased while SOD protein levels remained stable in comparison to healthy subjects. Also, the decrease in SOD activity was more pronounced in women with hyperplasia or adenocarcinoma than in those suffering from polypus or myoma, while higher levels of LOOH were recorded in all examined groups, in comparison to controls, except for patients with polypus endometrii. These results are in accordance with findings of other authors. Patients with cervicitis or myoma had lower plasma SOD activity and elevated lipid peroxida-
A

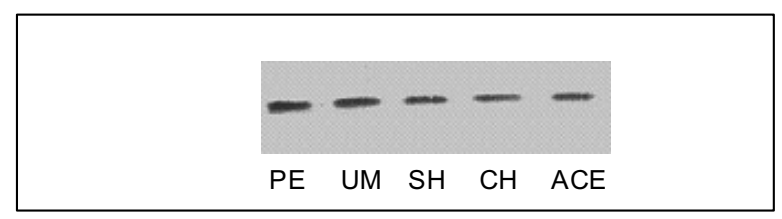

B

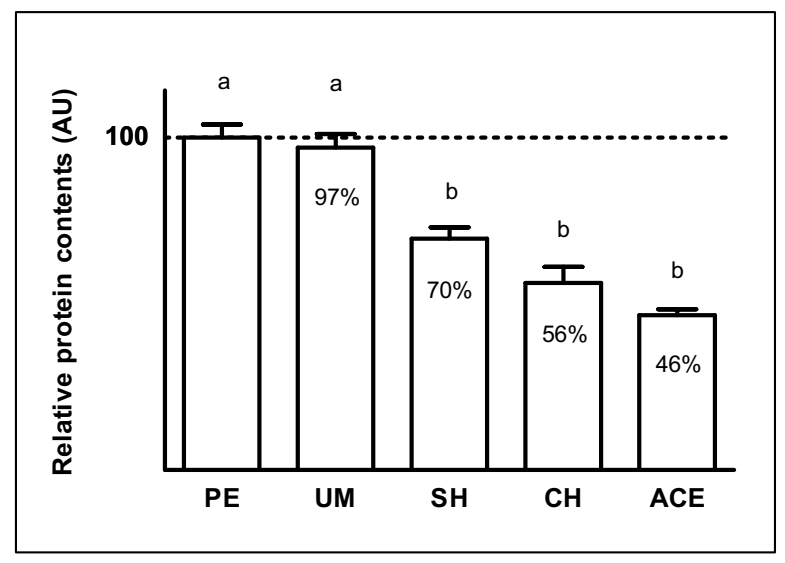

Fig. 4 - A. Relative protein contents. Example of Western blot immunoassay for CuZnSOD in the endometrium of patients diagnosed with polypus endometrii (PE), uterus myomatosus (UM), simple hyperplasia $(\mathrm{SH})$, complex hyperplasia $(\mathrm{CH})$ and adenocarcinoma endometrii (ACE). B. Comparison of relative SOD protein contents in endometrium patients diagnosed with polypus endometrii (PE), uterus myomatosus (UM), simple hyperplasia (SH), complex hyperplasia $(\mathrm{CH})$ and adenocarcinoma endometrii (ACE). Values are expressed in arbitrary units (AU), as a percent of the protein content in PE patients which is considered as $100 \%$ (mean $\pm \mathrm{SEM}$ ). Values not designated by the same letter $(a, b)$ are significantly different $(p<0.05)$. 
tion, compared to healthy women, whereas erythrocyte SOD activity was significantly lower only in myoma patients (Chiou and Hu 1999). Decreased SOD activity and enhanced lipid peroxidation were found in erythrocytes of cervical cancer patients as well, compared to healthy subjects and cervicitis patients (Manoharan et al. 2004).

A profound decrease in SOD activity and an increase in lipid peroxidation were also found in endometrium of patients with hyperplasia simplex, hyperplasia complex and adenocarcinoma, in comparison to women with polypus or myoma. In adenocarcinoma patients, we observed a more pronounced decrease in SOD activity than in hyperplastic subjects. Levels of SOD protein were found to be $30-45 \%$ lower in endometrial tissue with hyperplasia or adenocarcinoma, compared to polypus and myoma. Previous analysis of endometrial samples from two different human populations (Japanese and Finnish women) showed significantly decreased SOD activity and higher LPO in endometrium of cancer patients than in the normal tissue, which pointed to an impairment in the enzymic AO defense system (Punnonen et al. 1993). Lower SOD concentrations were recorded in the peritoneal fluid of infertile women with endometriosis (Liu et al. 2001, Szczepanska et al. 2003). Recent evidence also indicates decreased SOD activity and expression in many disease states or pathological conditions, including cancer (Bostwick et al. 2000, Cullen et al. 2003). Other studies, however, showed that SOD levels or activities in various tissues with neoplastic changes appeared unchanged or elevated compared to normal tissues (Balasubramaniyan et al. 1994, Chung-man Ho et al. 2001, $\mathrm{Hu}$ et al. 2005). Such observations are likely because of the different assays and various cell types used in those studies.

Decrease of enzyme activity could be a consequence of elevated endogenous ROS production, as indicated by several studies. Kong et al. (2000) showed that, in response to oxidative stress, SOD enzyme may be consumed to prevent oxidative damage since it was shown that the overproduction of ROS exhausts the SOD capacity. Similar observation was recorded by Onodera et al. (2003) regarding the antioxidant defense system in general. It was also shown that oxygen radical production, which elevates lipid peroxidation, increases with clinical progression of diseases (Bagchi and Puri 1998, Skrzydlewska et al. 2005). In support of these observations, we found negative correlation between $\mathrm{LOOH}$ and SOD activity in blood and endometrial tissue.

Evidence suggests that transformed tissues produce high levels of ROS and are constantly under oxidative stress (Hileman et al. 2001). The increase in ROS, such as $\mathrm{O}_{2}^{-}$, is able to stimulate cell cycle progression and promote cell proliferation. Although the precise mechanisms responsible for such elevation of ROS are not yet defined, several potential mechanisms have been suggested. They include the oncogenic signals, such as $c$ $m y c$ and Ras (Hu et al. 2005) or mitochondrial mutations and respiratory chain malfunction, which may lead to increased superoxide production (Pelicano et al. 2004). In addition, molecular mechanisms by which the expression of cytosolic SOD responds to ROS stress, have not been well characterized (Hu et al. 2005). Decreased cytosolic SOD level in gynecological disorders, observed in our study, may be due to a reduced expression of the SOD gene. Other possibilities include a diminished translation rate for SOD mRNA in endometrial hyperplastic and carcinoma cells. Such a discrepancy in mRNA levels and the levels of corresponding proteins, suggesting possible translational regulation, has been reported for many gene products in normal and malignant cells (Klausner et al. 1993, Bommer et al. 2004, Lauer et al. 1999). In addition, Brown et al. (2004) demonstrated an essential role of $\mathrm{O}_{2}$ or $\mathrm{O}_{2}^{--}$in the posttranslational activation of $\mathrm{CuZnSOD}$ and in the ratio of active to inactive $\mathrm{CuZnSOD}$, which may be relevant to various diseases.

Most studies have shown both in vivo and in vitro that antioxidant enzyme levels are altered in neoplastic changes. One of the consequences of AO enzyme imbalance is an alteration in cellular redox state (Oberley 2002). Cell damage caused by activated oxygen metabolites and reduced antioxidant capacity might be responsible for certain characteristics of malignant cells and biological differences between neoplastic and normal tissues (Oberley and Oberley 1997, Toyokuni 2006). Lower SOD activity and expression, as well as increased LOOH concentration, observed in our study, indicate that patients with benign, and particularly with premalignant and malignant gynecological diseases, are likely to be under relatively high levels of oxidative stress. 
Recent findings show that SOD might be a promising therapeutic target for cancer treatment. Depending on the cell type and the level of SOD activity, inhibition or enhancement of SOD using molecular biology techniques reflects two possible approaches to cancer therapy. For the cells with lower SOD activity, enhancement of SOD expression may be used to reverse the premalignant and malignant phenotype (Hileman et al. 2001).

Our study shows that gynecological patients have lower SOD activity in both blood and endometrium, while the SOD protein level is decreased only in the endometrial tissue. There is a possibility that women with hyperplasia or adenocarcinoma are more susceptible to oxidative stress since a more pronounced decrease of SOD level was observed in those patients.

Further investigation is necessary to reveal if alterations of SOD may contribute to the understanding of molecular mechanisms of carcinogenesis and to the development of new therapeutic approaches in clinical practice.

\section{ACKNOWLEDGMENTS}

The work was financially supported by the Ministry of Science and Technology of the Republic of Serbia (Grants 143044B and 143035B).

\section{RESUMO}

Resultados epidemiológicos e experimentais apontam para o envolvimento dos radicais derivados do oxigênio na patogênese das moléstias ginecológicas, assim como no desenvolvimento do câncer. O objetivo do presente estudo foi o de examinar as alterações nas atividades e níveis de $\mathrm{Cu} / \mathrm{Zn}$ superóxido dismutase (CuZnSOD) e hidroperóxidos lipídicos (LOOH) no sangue e tecido endometrial de pacientes diagnosticados com mioma uterino, pólipo endometrial, hiperplasia simplex, hiperplasia complex e adenocarcinoma do endométrio. Os resultados de nosso estudo mostraram atividades de SOD diminuídas e nível de SOD proteína inalterado no sangue de todos os pacientes examinados em comparação a indivíduos saudáveis. Diminuição de ambos, atividade de SOD e nível protéico, foram encontrados no endométrio de pacientes com hiperplasia simplex, hiperplasia complex e adenocarcinoma em comparação às mulheres com pólipos e/ou mioma. O nível de $\mathrm{LOOH}$ estava elevado em ambos os tecidos de pacientes com hyperplasia e adenocarcinoma em comparação a indiví- duos saudáveis ou pacientes com diagnóstico benigno. Nossos resultados sugerem que um decréscimo na atividade e nível protéico de SOD, assim como um incremento no nível de $\mathrm{LOOH}$, em pacientes com desordens ginecológicas, tornam esses pacientes mais susceptíveis ao dano oxidativo causado pelas espécies reativas de oxigênio (ROS). Um desequilíbrio na formação de ROS e no nível de SOD pode ser importante na patogênese e/ou perpetuação do dano tecidual em pacientes ginecológicos. Desde que existe evidência de que SOD pode ser um alvo para terapia de câncer, nossos resultados fornecem uma base para futura pesquisa e opções para aplicações clínicas.

Palavras-chave: $\mathrm{Cu} / \mathrm{Zn}$ superóxido dismutase, hidroperóxidos lipídicos, mioma uterino, pólipo endometrial, hiperplasia endometrial, adenocarcinoma endometrial.

\section{REFERENCES}

BAGCHI K AND PURI S. 1998. Free radicals and antioxidants in health and disease. East Mediterr Health J 4: 350-360.

BALASUBRAMANIYAN N, SUBRAMANIAN S AND GOVINDASAMY S. 1994. Status of antioxidant systems in human carcinoma of uterine cervix. Cancer Lett 87: 187-192.

Bommer UA, Lazaris-Karatzas A, De Benedetti A, Nurnberg P, Benndorf R, Bielka H and SonenBERG N. 1994. Translational regulation of the mammalian growth-related protein P23: involvement of eIF4E. Cell Mol Biol Res 40: 633-641.

Bostwick DG ET AL. 2000. Antioxidant enzyme expression and reactive oxygen species damage in prostatic intraepithelial neoplasia and cancer. Cancer 89: 123-134.

BRIGELIUS-FlOHÉ R. 2006. Glutathione peroxidases and redox-regulated transcription factors. Biol Chem 387: $1329-1335$.

Brown NM, TORRES AS, DoAn PE AND O'HALloran TV. 2004. Oxygen and the copper chaperone CCS regulate posttranslational activation of $\mathrm{Cu}, \mathrm{Zn}$ superoxide dismutase. Proc Natl Acad Sci 101: 5518-5523.

Chiou JF AND Hu ML. 1999. Elevated lipid peroxidation and disturbed antioxidant enzyme activities in plasma and erythrocytes of patients with uterine cervicitis and myoma. Clin Biochem 32: 189-192.

Chung-Man Ho J, Zheng S, Comhair SA, Farver C AND ERZURUM SC. 2001. Differential expression of manganese superoxide dismutase and catalase in lung cancer. Cancer Res 61: 8578-8585.

Cullen JJ, Mitros FA And Oberley LW. 2003: Expression of antioxidant enzymes in diseases of the human 
pancreas: Another link between chronic pancreatitis and pancreatic cancer. Pancreas 26: 23-27.

DRÖGE W. 2002. Free radicals in the physiological control of cell function. Physiol Rev 82: 47-95.

Hileman EA, Achanta G and Huang P. 2001. Superoxide dismutase: An emerging target for cancer therapeutics. Expert Opin Ther Targets 5: 697-710.

Hu Y, Rosen DG, Zhou Y, Feng L, YAng G, LiU J And HuANG P. 2005. Mitochondrial manganese-superoxide dismutase expression in ovarian cancer: role in cell proliferation and response to oxidative stress. J Biol Chem 280: 39485-39492.

Klausner RD, Rouault TA and Harford JB. 1993. Regulating the fate of mRNA: the control of cellular iron metabolism. Cell 72: 19-28.

Kong Q, Beel JA And Lillehei KO. 2000. A threshold concept for cancer therapy. Med Hypotheses 55: 29-35.

LAEMMLI UK. 1970. Cleavage of structural proteins during the assembly of the head of bacteriophage T4. Nature 227: 680-685.

Lauer C, Völkl A, Riedl S, Fahimi HD and Beier K. 1999. Impairment of peroxisomal biogenesis in human colon carcinoma. Carcinogenesis 20: 985-989.

LIU Y, LUO L AND ZHAO H. 2001. Levels of lipid peroxides and superoxide dismutase in peritoneal fluid of patients with endometriosis. J Tongji Med Univ 21: 166-167.

LOWRY OH, ROSEBROUGH NJ, FARR AL AND RANDALL RJ. 1951. Protein measurement with the Folin phenol reagent. J Biol Chem 193: 265-275.

Manoharan S, Kolanjiappan K and Kayalvizni M. 2004. Enhanced lipid peroxidation and impaired enzymic antioxidant activities in the erythrocytes of patients with cervical carcinoma. Cell Mol Biol Lett 9: 699-707.

MONARI M ET AL. 2006. Superoxide dismutase in gastric adenocarcinoma: is it a clinical biomarker in the development of cancer? Biomarkers 11: 574-584.

Münstedt K, Grant P, Woenckhaus J, Roth G and TINNEBERG HR. 2004. Cancer of the endometrium: current aspects of diagnostics and treatment. World J Surg Oncol 2: 24.

MUTTER GL. 2002. Diagnosis of premalignant endometrial disease. J Clin Pathol 55: 326-331.

OBERLEY TD. 2002. Oxidative damage and cancer. Am J Pathol 160: 403-408.
Oberley TD AND Oberley LW. 1997. Antioxidant enzyme levels in cancer. Histol Histopathol 12: 525-535.

OnOdera K, OMOI N-O, FukUi K, Hayasaka T, ShinKAi T, SuzUKi S, ABE K And Urano S. 2003. Oxidative damage of rat cerebral cortex and hippocampus, and changes in antioxidative defense systems caused by hyperoxia. Free Radic Res 37: 367-372.

Ota H, Igarashi S, Hatazawa M and Tanaka T. 1999. Immunohistochemical assessment of superoxide dismutase expression in the endometrium in endometriosis and adenomyosis. Fertil Steril 72: 129-134.

Pejić S, Kasapović J, Todorović A, Stojiljković V AND PAJOVIĆ SB. 2006. Lipid peroxidation and antioxidant status in blood of patients with uterine myoma endometrial polypus, hyperplastic and malignant endometrium. Biol Res 39: 71-82.

Pelicano H, Carney D and Huang P. 2004. ROS stress in cancer cells and therapeutic implications. Drug Resist Updat 7: 97-110.

Punnonen R, Kudo R, Punnonen K, Hietanen E, Kuoppala T, Kainulainen H, Sato K and AhoTUPA M. 1993. Activities of antioxidant enzymes and lipid peroxidation in endometrial cancer. Eur J Cancer 29A: 266-269.

SKRZYDLEWSKA E, SUlKowsKi S, KodA M, ZALEWSKI B, Kanczuga-Koda L And SulkowsKa M. 2005. Lipid peroxidation and antioxidant status in colorectal cancer. World J Gastroenterol 11: 403-406.

SZCZEPANSKA M, KoZLIK J, SKRZYPCZAK J AND MiKoLAJCZYK M. 2003. Oxidative stress may be a piece in the endometriosis puzzle. Fertil Steril 79: 1288-1293.

TOYOKUNI S. 2006. Novel aspects of oxidative stress-associated carcinogenesis. Antioxid Redox Signal 8: 1373 1377.

VAlko M, Leibfritz D, Moncol J, Cronin MT, MAZUR M AND TELSER J. 2007. Free radicals and antioxidants in normal physiological functions and human disease. Int J Biochem Cell Biol 39: 44-84.

Zelko IN, Mariani TJ And Folz RJ. 2002. Superoxide dismutase multigene family: A comparison of the $\mathrm{CuZn}$ SOD (SOD1), Mn-SOD (SOD2), and EC-SOD (SOD3) gene structures, evolution, and expression. Free Radic Biol Med 33: 337-349. 